\title{
Functionalized Macrocycles. I. Synthesis of Thiol-bearing Crown Ethers as an Approach to Regioselective Catalysts ${ }^{1,2}$ )
}

\author{
Takeaki Matsui and Kenji Koga \\ Faculty of Pharmacentical Sciences, University of Tokyo ${ }^{3)}$
}

(Received March 13, 1979)

\begin{abstract}
The rates of transacylation were studied between crown ethers $(\mathbf{1}, \mathbf{2}, 3)$ having sulfhydryl groups at the end of side arms of different lengths and $\alpha_{-}, \beta-, \gamma-$, and $\varepsilon$-amino acid $p$-nitrophenyl ester salts $(4,6,7,8)$. It was shown that regioselectivity of the reaction can be successfully correlated with the distance of the catalytic site from the polyether ring. It was also shown that introduction of ether oxygen in the side arm can be used to keep the side arm sticking up from the polyether ring in the complex.
\end{abstract}

Keywords_-crown ether; transacylation; regioselectivity; binding site; catalytic site; regio-recognition site; thiolysis; conformation

It is a major aim of synthetic organic chemistry to devise useful methods for the construction of desired compounds with high efficiency. Many investigations have hitherto been done along this line, and many strategies have been developed to date. Although artificial reactions still have much problems to be solved, nature seems to have solved them, because reactions in biological systems seem to be ideal in this sense. It is therefore interesting and important to study what sorts of strategies are operative to make reactions highly efficient in biological systems and how such strategies can be applied to organic synthetic reactions.

It is said that one of the striking differences between biological and artificial reactions is that the formation of highly structured enzyme-substrate complexes play an essential role in the former. ${ }^{4)}$ We therefore considered the formation of highly structured complexes in solution as one possible approach to make reactions highly efficient, and a research program directed to the synthesis of various macrocyclic compounds bearing functional groups at appropriate positions was initiated in our laboratory to study the possibility of designing new types of efficient catalysts having a site for substrate binding and a site for chemical transformation of the bound substrate.

Extensive investigations have already been reported on the utility of macrocyclic compounds such as cyclodextrins, ${ }^{5)}$ cyclophanes, ${ }^{6)}$ cyclic peptides, ${ }^{7)}$ crown ethers, ${ }^{8)}$ etc., to capture

1) A part of this work was published as a communication: T. Matsui and K. Koga, Tetrahedron Lett., 1978, 1115.

2) To avoid confusion in nomenclature, all crown ethers in this paper are considered as having the parent skeleton $\mathrm{A}$, which is named 1,2-bis $(\mathrm{X})-18$-crowr-6.

3) Location: 7-3-1, Hongo, Bunkyo-ku, Tokyo 113, Japan.

4) A.L. Lehninger, "Biochemistry," Worth Publishers, Inc., New York, 1975, p. 183.

5) M.L. Bender and M. Komiyama, in "Bioorganic Chemistry," Vol. 1, ed. by E.E. van Tamelen, Academic Press, New York, 1977, p. 25, and references cited therein.

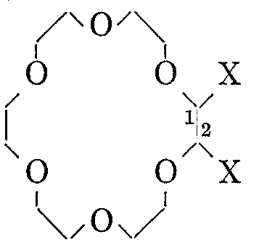

A

6) a) R. Hershfield and M.L. Bender, J. Am. Chem. Soc., 94, 1376 (1972); b) Y. Murakami, Y. Aoyama, M. Kida, and A. Nakano, Bull. Chem. Soc. Jpn., 50, 3365 (1977); c) I. Tabushi, Y. Kimura, K. Yamamura, J. Am. Chem. Soc., 100, 1304 (1978), and references cited in these papers.

7) a) V. Madison, C.M. Deber, and E.R. Blout, J. Am. Chem. Soc., 99, $4788(1977)$; b) Y. Murakami, A. Nakano, K. Matsumoto, and K. Iwamoto, Bull. Chem. Soc. Jpn., 51, 2690 (1978), and references cited in these papers.

8) a) D.J. Cram, in "Applications of Biochemical Systems in Organic Chemistry," Part II, ed. by J.B. Jones, C.J. Sih, and D. Perlman, John Wiley and Sons, Inc., New York, 1976, p. 815; b) D.J. Cram and J.M. Cram, Acc. Chem. Res., 11, 8 (1978); c) M. Hiraoka, "Crown Kagōbutsu," Kodansha, Tokyo, 1978 , and references cited in these papers. 
guest molecules in solution. Recently, Cram and his co-workers have reported enantioselective transacylation reactions between $\alpha$-amino acid $p$-nitrophenyl ester salts and optically active crown ethers having sulfhydryl groups as catalytic sites. ${ }^{9 a}$ ) Lehn and his co-workers have also reported enhanced rates of transacylation with high structural and chiral recognition in reactions between an optically active crown ether bearing a cysteinyl residue and dipeptide $p$-nitrophenyl ester salts. ${ }^{9 b)}$ We report here the results of our examinations on regioselectivity in the transacylation reactions between crown ethers $(1,2$, or 3$)$ having sulfhydryl groups at the ends of side arms of different lengths and $\alpha-\mathrm{N}$-methyl- $\alpha-, \beta-, \gamma-$, or $\varepsilon_{\text {-amino acid }}$ $p$-nitrophenyl ester salts $(\mathbf{4}, \mathbf{5}, \mathbf{6}, \mathbf{7}$, or $\mathbf{8}$, respectively). These crown ethers were designed to show regioselectivity in the expectation that the cyclic polyether moiety would act as a binding site, side arms constructed with ether oxygen and/or methylene as regio-recognition, sites, and sulfhydryl groups as catalytic sites, as shown in Fig. 1. These compounds have $\mathrm{a}_{2}$ symmetry as indicated, and are therefore no-sided.<smiles>SCC1OCCOCCOCCOCCOC1CS</smiles><smiles>SCCCC1OCCOCCOCCOCCO1</smiles><smiles>CCOC[C@H](OCCOCCOCCO)C(COCCS)OCCOCCS</smiles>

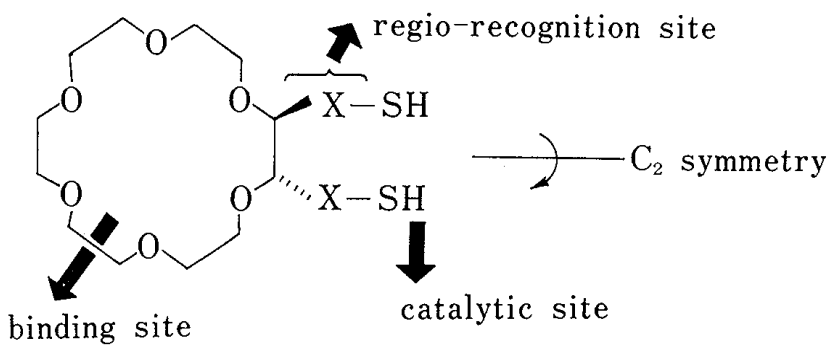

Fig. 1

\section{Results and Discussion}

\section{Synthesis of Crown Ethers (1, 2, and 3)}

Crown ethers $(1,2$, and 3 ) having side arms of different lengths were synthesized from $(+)$-tartaric acid (9).

Chart 1 shows the syntheses of 1 and 3 . The diol $(\mathbf{1 0})^{10)}$ was treated with pentaethyleneglycol ditosylate in DMSO in the presence of potassium tert-butoxide. 1,2-Bis(benzyloxymethyl)-18-crown-6 (11) was isolated in as high as 47\% yield, probably due to the so-called template effect. ${ }^{11)}$ Catalytic hydrogenolysis of $\mathbf{1 1}$ followed by tosylation afforded the ditosylate (12), which was converted to the corresponding dithiol ester (13). Lithium aluminum hydride reduction of 13 gave the desired crown dithiol (1).

On the other hand, extension of the length of the side arms of $\mathbf{1 1}$ by one ethyleneoxy unit was performed as usual to give 14. A series of reactions as described in the synthesis of 1 afforded the crown dithiol (3).

9) a) Y. Chao and D.J. Cram, J.Am.Chem. Soc., 98, $1015(1976)$; b) J.M. Lehn and C. Sirlin, Chem. Commun., 1978, 949 .

10) W.D. Curtius, D.A. Laidler, J.F. Stoddart, and G.H. Jones, Chem. Commun., 1975, 833.

11) R.N. Greene, Tetrahedron Lett., 1972, 1793. 


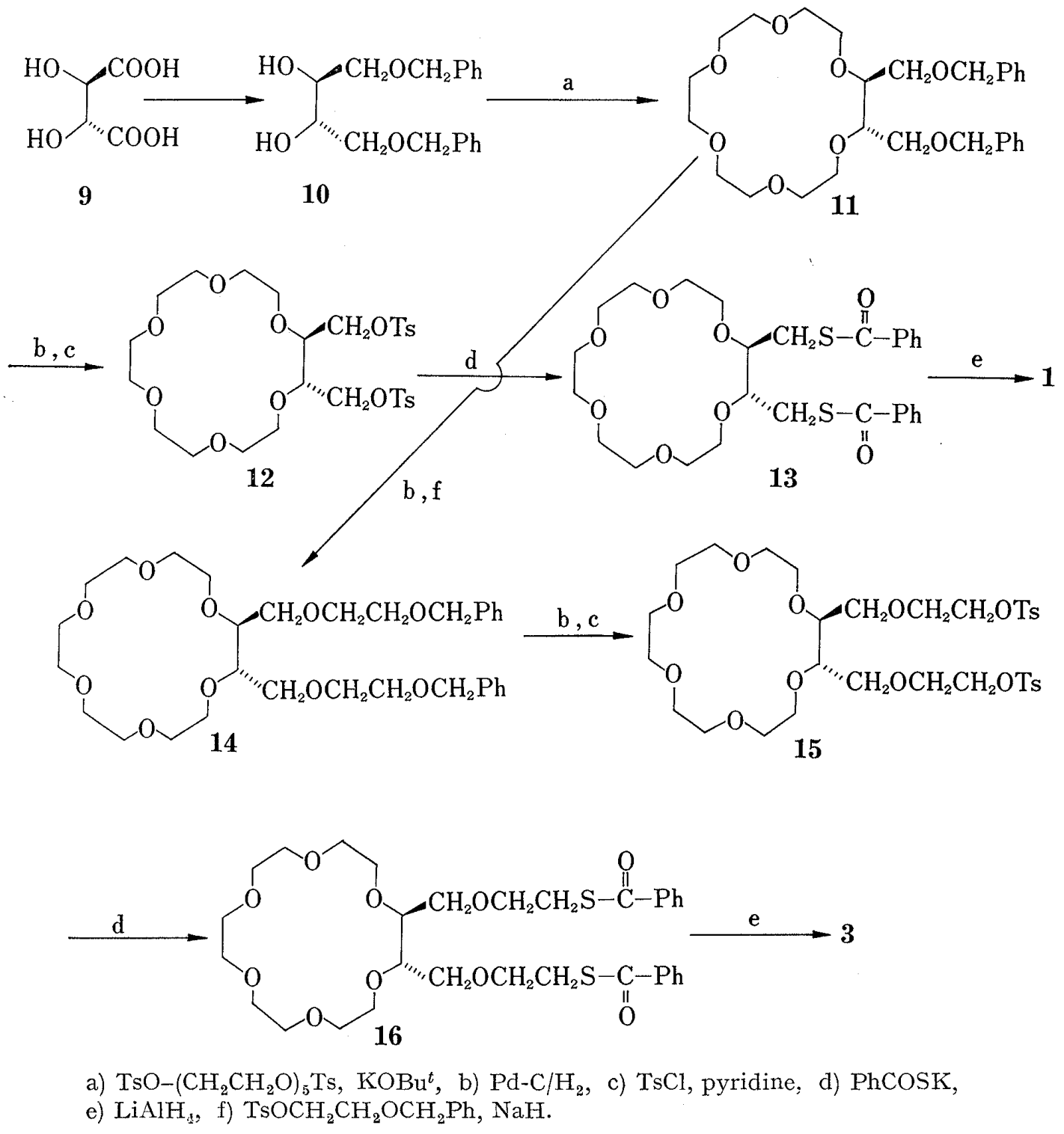

Chart 1

Chart 2 shows the synthesis of 2. Desulfurization of the 1,3-dithiolane derivative (18), prepared from the diiodide $(17)^{12)}$ and ethyl 1,3-dithiolane-2-carboxylate, ${ }^{13)}$ afforded the corresponding diester (19). The diol (22) was obtained from 19 by the usual method, and was converted to the crown dithiol (2) by the procedure described above.

\section{Mechanism of the Reaction}

Table I lists the pseudo-first-order rate constants for the release of $p$-nitrophenol from amino acid $p$-nitro-phenyl ester salts $(\mathbf{4}, \mathbf{5}, \mathbf{6}, \mathbf{7}$, and $\mathbf{8})$ in the absence and presence of 18-crown-6, 18-crown-6 and butanethiol, 1, 2, and 3. Table II lists the values of $k_{2} / k_{1}, k_{3} / k_{1}$, and $k_{3} / k_{2}$, the relative rates of $p$-nitrophenol release by 2 and 3 using 1 or 2 as a standard.

As shown in Chart 3 , the present reaction system is considered to include at least two competitive reactions occurring in the complex (27) formed between the crown ether and a substrate having a primary ammonium group: one is the acyl transfer reaction to form the thiol ester complex (28) and the second is the buffer solvolysis reaction to form the ethyl ester

12) L.J. Rubin, H.A. Lardy, and H.O.L. Fischer, J. Am. Chem. Soc., 74, 425 (1952).

13) I. Minamida, Y. Ikeda, K. Uneyama, W. Tagaki, and S. Oae, Tetrahedron, 24, 5293 (1968). 
complex (29). In either case, formation of the complex in advance of reaction is highly probable, ${ }^{8,9)}$ and the data obtained here support this view. For example, the rate constants for $p$-nitrophenol release from the glycine ester salt (4) and its $N$-methyl derivative (5) in the presence of crown ethers differ greatly, indicating effective complex formation in the reactions of 4 , which has a primary ammonium group. The rate ratio (310) of $p$-nitrophenol release from 7 in the absence and presence of 18-crown-6 supports this conclusion. Thus,<smiles>CCOC(=O)C1(CC2(CC3OC(C)(C)OC3CC3(C(=O)OCC)SCCS3)OC(C)(C)O[C@@H]2CC)O[C@H](CC)[C@@H](CC)O1</smiles><smiles>[R]OCCC[C@H]1OC(C)(CCCC)O[C@@H]1CCCO[R]</smiles>

19

$20: \mathrm{R}=\mathrm{H}$

$21: \mathrm{R}=\mathrm{CH}_{2} \mathrm{Ph}$

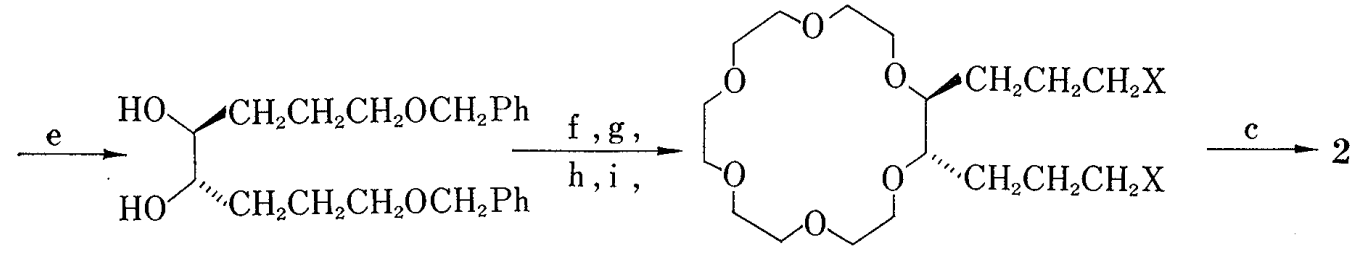

22

$$
\begin{aligned}
& 23: \mathrm{X}=\mathrm{OCH}_{2} \mathrm{Ph} \\
& 24: \mathrm{X}=\mathrm{OH} \\
& 25: \mathrm{X}=\mathrm{OTs} \\
& 26: \mathrm{X}=\mathrm{SCOPh}
\end{aligned}
$$

a) $\Gamma_{-\mathrm{S}}^{\mathrm{S}}>--\mathrm{COOC}_{2} \mathrm{H}_{5}, \mathrm{LDA}$, b) Raney Ni, c) $\mathrm{LiAlH}_{4}$, d) $\mathrm{PhCH}_{2} \mathrm{Cl}, \mathrm{NaH}$, e) $\mathrm{HCl}$,

f) $\left.\mathrm{TsO}-\left(\mathrm{CH}_{2} \mathrm{CH}_{2} \mathrm{O}\right)_{5} \mathrm{Ts}, \mathrm{KOBu}{ }^{t}, \mathrm{~g}\right) \mathrm{Pd}-\mathrm{C} / \mathrm{H}_{2}$, h) TsCl, pyridine, i) PhCOSK.

\begin{tabular}{|c|c|c|c|c|c|c|}
\hline \multirow{2}{*}{ Ester \rown ether } & \multicolumn{5}{|c|}{$10^{5} k\left(\mathrm{sec}^{-1}\right)$} & \multirow[b]{2}{*}{$3^{c)}$} \\
\hline & None & $\begin{array}{c}18- \\
\text { Crown-6 }\end{array}$ & $\begin{array}{c}18-\text { Crown }-6 \\
\left.+\mathrm{BuSH}^{b}\right)\end{array}$ & $1^{c)}$ & $2^{c)}$ & \\
\hline $\mathrm{Br}^{-} \mathrm{H}_{3} \mathrm{~N}^{+}-\mathrm{CH}_{2}-\mathrm{COOC}_{6} \mathrm{H}_{4}-\mathrm{NO}_{2}-p(4)$ & 3 & 0.9 & 1 & 1170 & 50 & 2500 \\
\hline $\mathrm{Br}^{-} \mathrm{CH}_{3} \mathrm{~N}^{+} \mathrm{H}_{2}-\mathrm{CH}_{2}-\mathrm{COOC}_{6} \mathrm{H}_{4}-\mathrm{NO}_{2}-p$ (5) & 5 & 5 & 4 & 6 & 4 & 37 \\
\hline $\mathrm{Br}^{-} \mathrm{H}_{3} \mathrm{~N}^{+}-\left(\mathrm{CH}_{2}\right)_{2}-\mathrm{COOC}_{6} \mathrm{H}_{4}-\mathrm{NO}_{2}-p(6)$ & $<0.1$ & $<0.05$ & $<0.05$ & 0.4 & 7 & 2 \\
\hline $\mathrm{Br}^{-} \mathrm{H}_{3} \mathrm{~N}^{+}-\left(\mathrm{CH}_{2}\right)_{3}-\mathrm{COOC}_{6} \mathrm{H}_{4}-\mathrm{NO}_{2}-p(7)$ & 310 & 1 & 0.9 & 6 & 42 & 41 \\
\hline $\mathrm{Br}^{-} \mathrm{H}_{3} \mathrm{~N}^{+}-\left(\mathrm{CH}_{2}\right)_{5}-\mathrm{COOC}_{6} \mathrm{H}_{4}-\mathrm{NO}_{2}-p(8)$ & $<0.05$ & $<0.05$ & $<0.05$ & $<0.05$ & $<0.05$ & $<0.05$ \\
\hline
\end{tabular}

Chart 2

TABle I. Pseudo-first-order Rate Constants for $p$-Nitrophenol Release from Amino Acid Ester Salts ${ }^{a}$ )

a) Rate constants were determined spectrometrically at $320 \mathrm{~nm}$ in $20 \%$ EtOH- $\mathrm{CH}_{2} \mathrm{Cl}_{2}$, buffered with $0.01 \mathrm{M}$ $\mathrm{AcOH}$ and $0.005 \mathrm{x}$ pyridine ( $\mathrm{pH} 4.60$ in water) at $25^{\circ}$, using $10^{-4} \mathrm{M}$ substrate ester and $5 \times 10^{-3} \mathrm{M}$ crown ether.

b) $10^{-2} \mathrm{M}$

c) Values are corrected for buffer solvolysis in the presence of 18-crown-6. 
TABLE II. Relative Rates of $p$-Nitrophenol Release ${ }^{a)}$

\begin{tabular}{cccc}
\hline \hline Ester & $k_{2} / k_{1}$ & $k_{3} / k_{1}$ & $k_{3} / k_{2}$ \\
\hline 4 & 0.043 & 2.1 & 50 \\
$\mathbf{6}$ & 17.5 & 5.0 & 0.3 \\
$\mathbf{7}$ & 7.0 & 6.8 & 1.0 \\
\hline
\end{tabular}

a) $k_{1}$ represents the rate constant in the presence of crown ether $\mathbf{i}$.
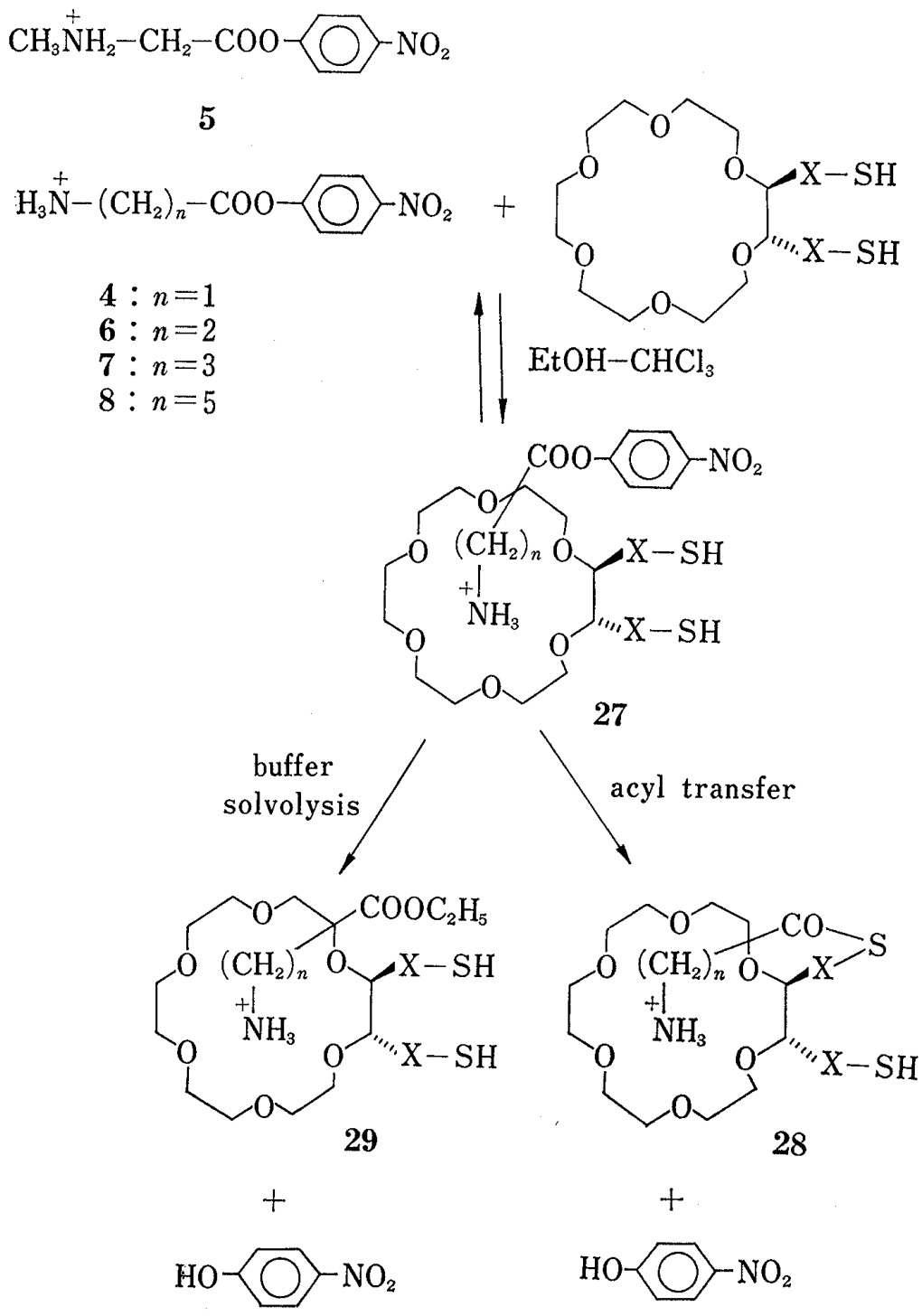

Chart 3

at the $\mathrm{pH}$ examined, the rate is fast in the absence of 18-crown-6 due to the formation of $\gamma$-lactam, while the rate becomes slow in the presence of 18-crown-6 due to the unavailability of the ammonium group as a result of preferential formation of the complex. Table I also shows the joint presence of 18-crown-6 and butanethiol is far less effective than 18-crown-6 having built-in sulfhydryl groups on side arms. It is clear that, in line with our expectation, the reaction occurs by initial formation of a complex between functionalized crown ether and amino acid ester salt, followed by attack of the built-in sulfhydryl group of the crown ether on the carbonyl group of the bound ester salt. 


\section{Regioselectivities in Acyl Transfer Reactions between Crown Ethers (1, 2, and 3) and Ester Salts $(4,5,6,7$, and 8$)$}

The following points are worthy of note (Tables I and II). (1) In the presence of $\mathbf{1}$, 2 or 3 , the rate of $p$-nitrophenol release from 4 is substantially larger than that from $\mathbf{5}$. This is considered to be due to complex formation in the case of 4 , resulting in an increase in the concentration of 4 near the sulfhydryl group of 1 . (2) In the presence of 1,4 showed an extraordinary large rate increase among the ester salts examined. This agrees well with our prediction based on a CPK molecular model of the 1.4-complex that the sulfhydryl group of 1 can come into close proximity to the carbonyl group of 4 without difficulty. (3) Increase in the length of the side arms by two methylene units from 1 to 2 changes the rates dramatically. Thus, the rate of 4 is decreased ( 0.043 fold), while those of 6 and 7 are increased (17.5 and 7.0 fold, respectively). This is also consistent with our prediction that regioselectivity of the reaction will move away from the ammonium group as

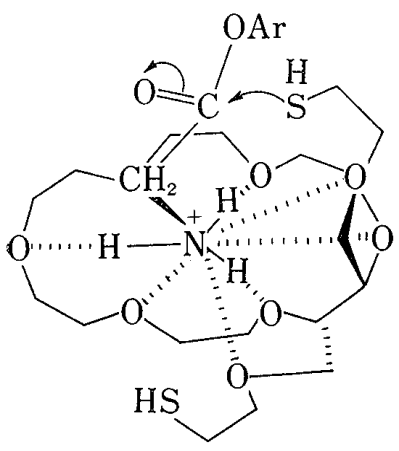

30 the position of the sulfhydryl group moves away from the polyether ring. (4) Further increase in the length of side arms by one ether oxygen unit from 2 to 3 also changes the rates. Contrary to our prediction, however, the rate of 4 is again, increased dramatically (50 fold using 2 as a standard, or 2.1 fold using 1 as a standard). This unexpected result can be rationalized by supposing additional pole-dipole interaction ${ }^{14}$ between the ammonium cation and the ether oxygen of the side arm, as shown in 30, or hydrogen bond formation between one of the hydrogens of the ammonium group and the ether oxygen of the side arm, resulting in fixation of the side arm

Fig. 2 conformation preferable for the reaction with 4 . In crown ethers, therefore, the introduction of an ether oxygen in the side arm may be useful to keep the side arm sticking up from the polyether ring in the complex.

The present data clearly demonstrate the feasibility of obtaining regioselectivity by the method described here. Synthetic approaches to functionalized crown ethers that can catalyze regioselective and enantioselective transacylation reactions are now in progress.

\section{Experimental ${ }^{15)}$}

$(1 S, 2 S)-1,2-B i s\left(\right.$ benzyloxymethyl)-18-crown-6 (11)-_- $\mathrm{KOBu}^{t}(26.9 \mathrm{~g} .0 .240 \mathrm{~mol})$ was added to a solution of $(2 S, 3 S)-(-)$-1,4-di-O-benzylthreitol $\left.(10)^{10}\right)(34.5 \mathrm{~g}, 0.114 \mathrm{~mol})$ in DMSO $(1125 \mathrm{ml})$ and the whole was stirred at $50^{\circ}$ under $\mathrm{N}_{2}$ for $2 \mathrm{hr}$. After cooling to room temperature, a solution of pentaethyleneglycol ditosylate $(63.3 \mathrm{~g}, 0.116 \mathrm{~mol})$ in DMSO $(375 \mathrm{ml})$ was added, and the resulting mixture was stirred at $70-80^{\circ}$ for $18 \mathrm{hr}$. The DMSO was removed in vacuo, the residue was mixed with $\mathrm{CHCl}_{3}$, and the insoluble materials were filtered off with the aid of Celite 545. After removal of the solvent, the residue was mixed with ether and $\mathrm{H}_{2} \mathrm{O}$, and the whole was shaken vigorously. The ether layer was separated, washed successively with $10 \%$ aq. $\mathrm{HCl}, \mathrm{H}_{2} \mathrm{O}$, satd. aq. $\mathrm{NaHCO}_{3}$, and satd. aq. $\mathrm{NaCl}$, then dried over $\mathrm{MgSO}_{4}$. Removal of the ether in vacuo afforded a brown oil $(55.1 \mathrm{~g})$, which was purified by column chromatography (silica gel, ether) to give $11(26.9 \mathrm{~g}, \mathrm{y} .47 \%)$ as a colorless oil. $[\alpha]_{\mathrm{D}}^{20}+4.0^{\circ}\left(c=2.4, \mathrm{CHCl}_{3}\right)\left(\right.$ reported $\left.^{16)}[\alpha]_{\mathrm{D}}^{25}+5.0^{\circ}\left(\mathrm{CHCl}_{3}\right)\right)$. IR

14) K.E. Koenig, R.C. Helgeson, and D.J. Cram, J. Am. Chem. Soc., 98, 4018 (1976).

15) All melting points are uncorrected. Optical rotations were measured with a Yanaco OR-50 photo direct reading polarimeter. Infrared (IR) spectra were recorded with a Jasco DS-402G infrared spectrometer. Ultraviolet (UV) absorptions were recorded with a Hitachi UV spectrometer, model 323. Nuclear magnetic resonance (NMR) spectra were recorded with a JNM-PS 100 spectrometer operating at 100 $\mathrm{MHz}$. Chemical shift values are expressed in ppm relative to internal tetramethylsilane. Abbreviations are as follows: $s$, singlet; $d$, doublet; $t$, triplet; $q$, quartet; $m$, multiplet. Mass spectra (MS) were measured with a JEOL JMS-01 SG-2 mass spectrometer.

16) N. Ando, Y. Yamamoto, J. Oda, and Y. Inoue, Synthesis, 1978, 688. 
$\nu_{\max }^{\mathrm{CHCl}_{3}} \mathrm{~cm}^{-1}:$ 1116. NMR $\left(\mathrm{CDCl}_{3}\right) \delta: 3.4-3.9\left(26 \mathrm{H}, \mathrm{m}\right.$, ring protons and two $\left.-\mathrm{CH}_{2}-\mathrm{O}-\mathrm{CH}_{2} \mathrm{C}_{6} \mathrm{H}_{5}\right), 4.48(4 \mathrm{H}, \mathrm{s}$, two $\left.-\mathrm{O}-\mathrm{CH}_{2}-\mathrm{C}_{6} \mathrm{H}_{5}\right), 7.24\left(10 \mathrm{H}\right.$, s, two $\left.\mathrm{C}_{6} \underline{\mathrm{H}}_{5}-\right)$. MS mle: $504\left(\mathrm{M}^{+}\right)$. Anal. Calcd. for $\mathrm{C}_{28} \mathrm{H}_{40} \mathrm{O}_{8}: \mathrm{C}, 66.64$; $\mathrm{H}, 7.99$. Found: $\mathrm{C}, 66.43 ; \mathrm{H}, 8.04$.

$(1 S, 2 S)-1,2$-Bis(tosyloxymethyl)-18-crown-6 (12)_-A mixture of $11(22.9 \mathrm{~g}), 10 \%$ Pd-C $(1.96 \mathrm{~g})$ and $\mathrm{AcOH}(1 \mathrm{ml})$ in EtOH-THF (1:1) $(200 \mathrm{ml})$ was shaken vigorously under atmospheric pressure of $\mathrm{H}_{2}$ at room temperature until the absorption of $\mathrm{H}_{2}$ ceased. The catalyst was filtered off, and the filtrate was evaporated to dryness to give a colorless oil (15.4 g) (MS mle: $\left.324\left(\mathrm{M}^{+}\right)\right)$. A mixture of this oil $(5.0 \mathrm{~g}, \mathrm{ca} .15 .4 \mathrm{mmol})$ and $\mathrm{TsCl}(8.80 \mathrm{~g}, 46.2 \mathrm{mmol})$ in pyridine $(32 \mathrm{ml})$ was stirred at $0^{\circ}$ for $48 \mathrm{hr}$. The mixture was poured into icecooled $10 \%$ aq. $\mathrm{HCl}$, and the whole was extracted with $\mathrm{CH}_{2} \mathrm{Cl}_{2}$. The combined extracts were washed successively with $10 \%$ aq. $\mathrm{HCl}, \mathrm{H}_{2} \mathrm{O}$, satd. aq. $\mathrm{NaHCO}_{3}$ and $\mathrm{H}_{2} \mathrm{O}$, then dried over $\mathrm{MgSO}_{4}$. Removal of the solvent gave $12(9.44 \mathrm{~g}, \mathrm{y} .97 \%$ ) as a pale yellow oil, which was purified by column chromatography (silica gel, AcOEt)

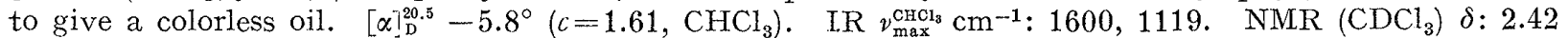
$\left(6 \mathrm{H}, \mathrm{s}\right.$, two- $\left.\mathrm{C}_{6} \mathrm{H}_{4}-\mathrm{CH}_{3}\right), 3.3-3.9\left(22 \mathrm{H}\right.$, m, ring protons), $3.9-4.4\left(4 \mathrm{H}, \mathrm{m}\right.$, two $\left.\mathrm{CH}-\mathrm{CH}_{2}-\mathrm{O}-\right), 7.28$ and 7.70 (4H, AB-q, $J=8 \mathrm{~Hz}$, aromatic protons). MS mle: $632\left(\mathrm{M}^{+}\right)$. Anal. Calcd. for $\mathrm{C}_{28} \mathrm{H}_{40} \mathrm{O}_{12} \mathrm{~S}_{2}: \mathrm{C}, 53.15 ; \mathrm{H}$, 6.37. Found: $\mathrm{C}, 52.61 ; \mathrm{H}, 6.26$.

$(1 \boldsymbol{R}, 2 R)$-1,2-Bis(benzoylthiomethyl)-18-crown-6 (13)__-A solution of 12 (997 mg, $1.58 \mathrm{mmol})$ and potassium monothiobenzoate $(669 \mathrm{mg}, 3.79 \mathrm{mmol})$ in EtOH $(12 \mathrm{ml})$ was heated under reflux for $6 \mathrm{hr}$ under $\mathrm{N}_{2}$. After cooling, the solvent was removed in vacuo, and the residue was shaken with a mixture of ether and $\mathrm{H}_{2} \mathrm{O}$. The ether layer was washed with $\mathrm{H}_{2} \mathrm{O}$, dried over $\mathrm{MgSO}_{4}$, and evaporated to dryness to give an oil, which was purified by column chromatography (silica gel, AcOEt) to give $\mathbf{1 3}(782 \mathrm{mg}, \mathrm{y} .88 \%$ ) as a colorless

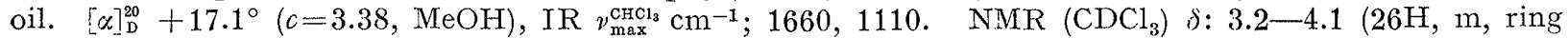
protons and two $\left.-\mathrm{CH}_{2}-\mathrm{S}-\mathrm{CO}-\mathrm{C}_{6} \mathrm{H}_{5}\right), 7.3-8.0\left(10 \mathrm{H}, \mathrm{m}\right.$, two $\left.\mathrm{C}_{6} \mathrm{H}_{5} \mathrm{CO}-\right)$. MS mle: $564\left(\mathrm{M}^{+}\right)$. Anal. Calcd. for $\mathrm{C}_{28} \mathrm{H}_{36} \mathrm{O}_{8} \mathrm{~S}_{2}: \mathrm{C}, 59.55 ; \mathrm{H}, 6.43 ; \mathrm{S}, 11.36$. Fourd: $\mathrm{C}, 59.41 ; \mathrm{H}, 6.39 ; \mathrm{S}, 11.16$.

$(1 R, 2 R)-1,2-B i s(m e r c a p t o m e t h y l)-18$-crown-6 (1)__. A solution of $13(3.72 \mathrm{~g}, 6.6 \mathrm{mmol})$ in ether $(70 \mathrm{ml})$ was added dropwise to a suspension of $\mathrm{LiAlH}_{4}(500 \mathrm{mg}, 13.2 \mathrm{mmol})$ in ether $(30 \mathrm{ml})$ under $\mathrm{N}_{2}$, and then the whole was stirred under reflux for $2 \mathrm{hr}$. Ether $(150 \mathrm{ml})$ and $\mathrm{H}_{2} \mathrm{O}(20 \mathrm{ml})$ were added to the cooled reaction mixture, then $5 \%$ aq. $\mathrm{HCl}$ was added to give $\mathrm{pHI} 2-3$. After addition of $\mathrm{H}_{2} \mathrm{O}(120 \mathrm{ml})$, the whole was shaken vigorously. The ether layer was separated, dried over $\mathrm{MgSO}_{4}$, and then evaporated to dryness under reduced pressure. The residue was purified by column chromatography (silica gel, ether) to give 1 (1.77 g, y. $75 \%$ ) as a colorless oil. $[\alpha]_{\mathrm{D}}^{19.5}-10.8^{\circ}\left(c=3.40, \mathrm{CHCl}_{3}\right)$ IR $\nu_{\max }^{\mathrm{CHCl}_{3}} \mathrm{~cm}^{-1}: 2590,1110 . \quad \mathrm{NMR}\left(\mathrm{CDCl}_{3}\right) \delta: \sim 1.6(2 \mathrm{H}$, two $\mathrm{t}, J=9 \mathrm{~Hz}$, two $-\mathrm{SH}), 2.4-2.9\left(4 \mathrm{H}, \mathrm{m}\right.$, two $\left.-\mathrm{CH}_{2} \mathrm{SH}\right), 3.3-3.9(22 \mathrm{H}, \mathrm{m}$, ring protons). Anal. Calcd. for $\mathrm{C}_{14} \mathrm{H}_{25} \mathrm{O}_{6} \mathrm{~S}_{2}: \mathrm{C}, 47.17 ; \mathrm{H}, 7.92$. Found: $\mathrm{C}, 46.91 ; \mathrm{H}, 7.65$.

$(1 S, 2 S)-1,2-B i s[(2-(b e n z y l o x y)$ ethoxy)methyl]-18-crown-6 (14)__-Catalytic hydrogenolysis of 11 as described previously afforded the corresponding debenzylated product as a colorless oil. A mixture of this oil $(3.57 \mathrm{~g}, 11.0 \mathrm{mmol}$ ) and $\mathrm{NaH}$ (prepared from $50 \% \mathrm{NaH}$ in oil $(1.37 \mathrm{~g}, 28.5 \mathrm{mmcl}$ ) by washing twice with hexane) in THF (28 ml) was stirred at $50^{\circ}$ for $1 \mathrm{hr}$. After cooling, a solution of 2-benzyloxyethyl p-toluenesulfonate $\left.^{17}\right)(10.1 \mathrm{~g}, 33.0 \mathrm{mmol})$ in DMSO $(42 \mathrm{ml})$ was added, and the whole was stirred at $70-80^{\circ}$ for $18 \mathrm{hr}$. Usual work-up as described above for the preparation of $\mathbf{1 1}$ afforded a brown oil, which was purified by column chromatography (silica gel, AcOEt) to give $14(4.08 \mathrm{~g}, \mathrm{y} .63 \%)$ as a colorless oil. $\quad[\alpha]_{\mathrm{D}}^{20}+0.5^{\circ}\left(c=7.6, \mathrm{CHCl}_{3}\right)$.

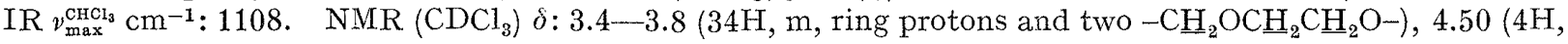
$\mathrm{s}$, two $\left.-\mathrm{OCH}_{2} \mathrm{C}_{6} \mathrm{H}_{5}\right), 7.26\left(10 \mathrm{H}\right.$, s, two $\left.\mathrm{C}_{6} \mathrm{H}_{5}-\right)$. MS m/e: $592\left(\mathrm{M}^{+}\right)$. Anal. Calcd. for $\mathrm{C}_{32} \mathrm{H}_{48} \mathrm{O}_{10}: \mathrm{C}, 64.84$; $\mathrm{H}, 8.16$. Found: $\mathrm{C}, 65.19 ; \mathrm{H}, 7.78$.

$(1 S, 2 S)-1,2-B i s[(2-($ tosyloxy) ethoxy) methyl]-18-crown-6 (15)__ A mixture of $14(3.56 \mathrm{~g})$ and $10 \% \mathrm{Pd}-\mathrm{C}$ $(500 \mathrm{mg})$ in EtOH-THF $(1: 1)(80 \mathrm{ml})$ was shaken vigorously at room temperature under atmospheric pres. sure of $\mathrm{H}_{2}$ until the absorption of $\mathrm{H}_{2}$ ceased. The catalyst was filtered off, and the filtrate was evaporated to dryness to give a colorless oil $(2.33 \mathrm{~g})$. A mixture of this oil $(205 \mathrm{mg}, \mathrm{ca} .0 .517 \mathrm{mmol})$ and $\mathrm{TsCl}(296 \mathrm{mg}$, $1.55 \mathrm{mmol}$ ) in pyridine $(6 \mathrm{ml})$ was stirred at $0^{\circ}$ for $48 \mathrm{hr}$. Usual work-up as described above for the preparation of 12 afforded crude $15(306 \mathrm{mg}$, y. $82 \%)$ as a pale yellow oil, which was purified by column chromatography (silica gel, AcOEt) to give a colorless oil. $[\alpha]_{\mathrm{p}}^{20}-0.8^{\circ}\left(c=5.8, \mathrm{CHCl}_{3}\right)$, IR $\nu_{\max }^{\mathrm{CHCl}_{3}} \mathrm{~cm}^{-1}: 1601,1119$. NMR $\left(\mathrm{CDCl}_{3}\right) \delta: 2.46\left(6 \mathrm{H}, \mathrm{s}\right.$, two $\left.\mathrm{CH}_{3}-\mathrm{C}_{6} \mathrm{H}_{4}-\right), 3.4-3.9\left(30 \mathrm{H}, \mathrm{m}\right.$, ring protons and two $\left.-\mathrm{CH}_{2} \mathrm{OCH}_{2} \mathrm{CH}_{2} \mathrm{O}-\right)$, $4.1-4.2\left(4 \mathrm{H}, \mathrm{m}\right.$, two $\left.\mathrm{CH}_{2} \mathrm{CH}_{2} \mathrm{OTs}\right), 7.26,7.68\left(8 \mathrm{H}, \mathrm{AB}-\mathrm{q}, J=8 \mathrm{~Hz}\right.$, two $\left.\mathrm{CH}_{3}-\mathrm{C}_{6} \underline{\mathrm{H}}_{4}-\mathrm{SO}_{2}-\right)$. Anal. Calcd. for $\mathrm{C}_{32} \mathrm{H}_{48} \mathrm{O}_{14} \mathrm{~S}_{2}: \mathrm{C}, 53.32 ; \mathrm{H}, 6.71$. Found: $\mathrm{C}, 52.86 ; \mathrm{H}, 6.46$.

(. $3,2 S)-1,2-B i s[(2-($ benzoylthio) ethoxy)methyl]-18-crown-6 (16)__-A solution of 15 (306 mg, $0.425 \mathrm{mmol})$ and potassium monothiobenzoate $(187 \mathrm{mg}, 1.06 \mathrm{mmol})$ in EtOH $(4 \mathrm{ml})$ was heated under reflux for $6 \mathrm{hr}$ under $\mathrm{N}_{2}$. Usual work-up as described above for the preparation of $\mathbf{1 3}$ afforded an oil, which was purified by column chromatography (silica gel, AcOEt) to give $16(187 \mathrm{mg}, \mathrm{y} .67 \%)$ as a pale pink oil. $[\alpha]_{\mathrm{D}}^{20}+4.9^{\circ}$ $(c=3.63, \mathrm{MeOH})$. IR $\nu_{\max }^{\mathrm{CHCl}_{3}} \mathrm{~cm}^{-1}: 1660,1115$. NMR $\left(\mathrm{CDCl}_{3}\right) \delta: 3.28\left(4 \mathrm{H}, \mathrm{t}, J=7 \mathrm{~Hz}\right.$, two $\left.-\mathrm{CH}_{2} \mathrm{C} \mathrm{H}_{2}-\mathrm{S}-\right)$, 3.5-3.9 (30H, m, ring protons and two $\left.\mathrm{CH}_{2} \mathrm{OCH}_{2} \mathrm{CH}_{2} \mathrm{~S}-\right), 7.2-7.9(10 \mathrm{H}, \mathrm{m}$, aromatic protons). Anal. Calcd. for $\mathrm{C}_{32} \mathrm{H}_{44} \mathrm{O}_{10} \mathrm{~S}_{2}: \mathrm{C}, 58.87 ; \mathrm{H}, 6.79$. Found: $\mathrm{C}, 58.37 ; \mathrm{H}, 6.77$.

$(1 S, 2 S)-1,2-B i s[(2-$ (mercapto) ethoxy) methyl]-18-crown $-6(3)-$ A solution of $16(328 \mathrm{mg}, 0.50 \mathrm{mmol})$ in

17) G.M. Bennett, J. Chem. Soc., 127, 1277 (1925). 
ether $(10 \mathrm{ml})$ was added dropwise to a suspension of $\mathrm{LiAlH}_{4}(76 \mathrm{mg}, 2.0 \mathrm{mmol})$ in ether $(4 \mathrm{ml})$ under $\mathrm{N}_{2}$, and then the whole was stirred under reflux for $2 \mathrm{hr}$. Usual work-up as described above for the preparation of 1 afforded an oil, which was purified by column chromatography (silica gel, ether) to give $3(132 \mathrm{mg}, \mathrm{y} .59 \%)$ as a colorless oil. $[\alpha]_{D}^{19.5}+2.5^{\circ}\left(c=2.6, \mathrm{CHCl}_{3}\right)$. IR $\nu_{\max }^{\mathrm{flm}} \mathrm{cm}^{-1}: 2554$. NMR $\left(\mathrm{CDCl}_{3}\right) \delta: 1.58(2 \mathrm{H}, \mathrm{t}, J=$ $8 \mathrm{~Hz}$, two $-\mathrm{SH}), 2.68\left(4 \mathrm{H}, \mathrm{m}\right.$, two $\left.\mathrm{CH}_{2} \mathrm{CH}_{2} \mathrm{SH}\right), 3.5-3.9\left(30 \mathrm{H}, \mathrm{m}\right.$, ring protons and two $\left.\mathrm{CH}_{2} \mathrm{OCH}_{2} \mathrm{CH}_{2} \mathrm{SH}\right)$. Anal. Calcd. for $\mathrm{C}_{18} \mathrm{H}_{36} \mathrm{O}_{8} \mathrm{~S}_{2}: \mathrm{C}, 48.62 ; \mathrm{H}, 8.16$. Found: C, 48.43; H, 7.92.

Diethyl (4S,5S)-2,2: 7,7-Bis(ethylenedithio)-4,5-isopropylidenedioxysuberate (18)—— $n$-BuLi in hexane $(45 \mathrm{ml}, 68 \mathrm{mmol})$ was added to a stirred solution of diisopropylamine $(6.90 \mathrm{~g}, 68.2 \mathrm{mmol})$ in THF (300 ml) under argon at $-78^{\circ}$. After $20 \mathrm{~min}$, a solution of ethyl 1,3-dithiolane-2-carboxylate ${ }^{13)}(11.2 \mathrm{~g}, 62.8 \mathrm{mmol})$ was added, and the whole was stirred for $20 \mathrm{~min}$. A solution of $(2 R, 3 R)$-1,4-dideoxy-1,4-diiodo-2,3-Oisopropylidenethreitol ${ }^{12)}(17)\left([\alpha]_{\mathrm{D}}^{23.5}-16.7^{\circ}(c=8.43, \mathrm{MeOH})\right)(10.0 \mathrm{~g}, 26.2 \mathrm{mmol})$ in THF $(100 \mathrm{ml})$ was added, and the reaction mixture was stirred for $20 \mathrm{~min}$ at $-78^{\circ}$, for $1 \mathrm{hr}$ at $-23^{\circ}$, for $3 \mathrm{hr}$ at $0^{\circ}$, and then for $1 \mathrm{hr}$ at room temperature. The reaction mixture was poured into ice-cooled aq. citric acid, and the whole was extracted with ether. The ethereal extracts were combined, washed with $\mathrm{H}_{2} \mathrm{O}$, dried over $\mathrm{MgSO}_{4}$, and evaporated to dryness. The residue was purified by column chromatography (silica gel, hexane-ether $(2: 1)$ ) to give $18(5.97 \mathrm{~g}$, y. $47 \%$ ) as a colorless solid. Recrystallization from ether afforded a colorless powder of $\operatorname{mp} 67-68^{\circ} . \quad[\alpha]_{\mathrm{D}}^{20}-43.6^{\circ}(c=2.01, \mathrm{EtOH}) . \quad \mathrm{IR} v_{\max }^{\mathrm{KBr}} \mathrm{cm}^{-1}: 1737 . \quad \mathrm{NMR}\left(\mathrm{CDCl}_{3}\right) \delta: \sim 1.3(12 \mathrm{H}, \mathrm{s}$, and $\mathrm{t}$, $J=7 \mathrm{~Hz},-\mathrm{O}-\mathrm{C}\left(\mathrm{CH}_{3}\right)_{2}-\mathrm{O}-$ and two $\left.\mathrm{CH}_{2} \mathrm{CH}_{3}\right), 2.4-2.6\left(4 \mathrm{H}, \mathrm{m}\right.$, two $\left.\mathrm{CH}-\mathrm{CH}_{2}-\mathrm{C}\right), 3.3-3.5$ (8H, m, two $-\mathrm{S}-$ $\left.\mathrm{CH}_{2} \mathrm{CH}_{2}-\mathrm{S}-\right)$, 3.7-3.8 (2H, m, two $\left.\mathrm{CH}-\mathrm{CH}_{2}-\mathrm{C}\right), 4.18\left(4 \mathrm{H}, \mathrm{q}, J=7 \mathrm{~Hz}\right.$, two $\left.-\mathrm{O}-\mathrm{C}_{2}-\mathrm{CH}_{3}\right)$. Anal. Calcd. for $\mathrm{C}_{19} \mathrm{H}_{30} \mathrm{O}_{6} \mathrm{~S}_{4}: \mathrm{C}, 47.27 ; \mathrm{H}, 6.26$. Found: $\mathrm{C}, 47.37 ; \mathrm{H}, 6.20$.

Diethyl $(\mathbf{4} S, 5 S)-4,5-I$ sopropylidenedioxysuberate $(19)-\mathrm{NaBH}_{4}(15.7 \mathrm{~g}, 0.415 \mathrm{~mol})$ was added in small portions to a solution of $\mathrm{NiCl}_{2} \cdot 6 \mathrm{H}_{2} \mathrm{O}(49.4 \mathrm{~g}, 0.208 \mathrm{~mol})$ in $\mathrm{EtOH}(300 \mathrm{ml})$ with stirring at room temperature, and the resulting suspension was stirred for an additional $\left.0.5 \mathrm{hr} .{ }^{18}\right)$ Compound $18(5.0 \mathrm{~g}, 10.4 \mathrm{mmol})$ was added to this suspension, and the whole was refluxed for $33 \mathrm{hr}$. The reaction mixture was filtered, and insoluble materials were washed well with EtOH. The filtrate and washings were combined and evaporated to dryness. The residue was partitioned with ether and $\mathrm{H}_{2} \mathrm{O}$, and the ethereal layer was washed with satd. aq. $\mathrm{NaCl}$. The ether layer was dried over $\mathrm{MgSO}_{4}$ and evaporated to dryness, and the residue was distilled to give $19(1.37 \mathrm{~g}, \mathrm{y} .44 \%)$ as a colorless oil of bp $117-118^{\circ}(0.013-0.015 \mathrm{mmHg}) . \quad[\alpha]_{\mathrm{D}}^{20}-38.1^{\circ}(c=8.67$, EtOH). IR $\left.\nu_{\max }^{\mathrm{CHCl}_{3} \mathrm{~cm}^{-1}: 1720-1730 \text {. NMR } 1.27\left(6 \mathrm{H}, \mathrm{t}, J=7 \mathrm{~Hz} \text {, two } \mathrm{CH}_{3} \mathrm{CH}_{2}-\right), 1.36(6 \mathrm{H}, \mathrm{s}, \mathrm{O}-\mathrm{C}(\mathrm{CH}}\right)_{2}-$ $\mathrm{O}-), 1.7-2.1\left(4 \mathrm{H}, \mathrm{m}\right.$, two $\left.\mathrm{CH}-\mathrm{CH}_{2}-\mathrm{CH}_{2}-\mathrm{CO}-\right), 2.2-2.6\left(4 \mathrm{H}, \mathrm{m}\right.$, two $\left.\mathrm{CH}_{2} \mathrm{CH}_{2} \mathrm{COOC}_{2} \mathrm{H}_{5}\right), 3.5-3.7(2 \mathrm{H}, \mathrm{m}$, two $\left.\mathrm{O}-\mathrm{CH}-\mathrm{CH}_{2}-\right), 4.12\left(4 \mathrm{H}, \mathrm{q}, J=7 \mathrm{~Hz}\right.$, two $\left.-\mathrm{COOCH}_{2} \mathrm{CH}_{3}\right)$. Anal. Calcd. for $\mathrm{C}_{1.5} \mathrm{H}_{26} \mathrm{O}_{6}: \mathrm{C}, 59.58 ; \mathrm{H}, 8.67$. Found: C, 59.31; H, 8.59.

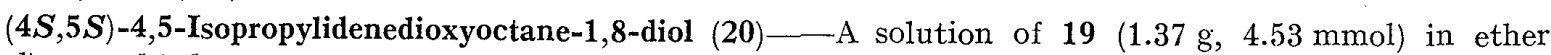
$(10 \mathrm{ml})$ was added to a suspension of $\mathrm{LiAlH}_{4}(760 \mathrm{mg}, 20.0 \mathrm{mmol})$ in ether $(20 \mathrm{ml})$, and the whole was refluxed for $4 \mathrm{hr}$. Water $(0.8 \mathrm{ml}), 15 \%$ aq. $\mathrm{NaOH}(0.8 \mathrm{ml})$ and $\mathrm{H}_{2} \mathrm{O}(2.2 \mathrm{ml})$ were added successively with ice cooling, and the reaction mixture was stirred for an additional $0.5 \mathrm{hr}$. Insoluble materials were filtered off and were washed well with ether. The combined filtrate and washings were dried over $\mathrm{MgSO}_{4}$ and evaporated to dryness. The residue was distilled to give crude $20(937 \mathrm{mg}, \mathrm{y} .95 \%)$ as a colorless oil of bp $124-129^{\circ}(0.1$ $\mathrm{mmHg})$. This sample was used for the next step without further purification.

$(4 S, 5 S)-1,8$-Dibenzyloxy-4,5-isopropylidenedioxyoctane $(21) —$ A mixture of 20 (344 mg, $1.58 \mathrm{mmol})$ and $\mathrm{NaH}$ (prepared from $50 \% \mathrm{NaH}$ in oil $(173 \mathrm{mg}, 3.6 \mathrm{mmol})$ by washing twice with hexane) in THF (2 ml) was stirred under argon at $50^{\circ}$ for $1 \mathrm{hr}$. After cooling, a solution of benzyl chloride $(830 \mathrm{mg}, 6.56 \mathrm{mmol})$ in DMSO $(3 \mathrm{ml})$ was added, and the whole was stirred at $70-80^{\circ}$ for $18 \mathrm{hr}$. The reaction mixture was taken up in benzene, and the whole was washed with $\mathrm{H}_{2} \mathrm{O}$ five times. The benzene solution was dried over $\mathrm{MgSO}_{4}$ and evaporated to dryness to give an oil, which was purified by column chromatography (silica gel, etherhexane $(1: 6))$ to give $21(432 \mathrm{mg}, \mathrm{y} .68 \%)$ as a colorless oil. $[\alpha]_{\mathrm{D}}^{20}-20.6^{\circ}\left(c=3.55, \mathrm{CHCl}_{3}\right)$. $\mathrm{NMR}\left(\mathrm{CDCl}_{3}\right)$ $\delta: 1.35\left(6 \mathrm{H}, \mathrm{s},-\mathrm{O}-\mathrm{C}\left(\mathrm{CH}_{3}\right)_{2}-\mathrm{O}-\right), 1.3-2.0\left(8 \mathrm{H}, \mathrm{m}\right.$, two $\left.-\mathrm{CH}-\mathrm{CH}_{2} \mathrm{CH}_{2} \mathrm{CH}_{2} \mathrm{O}-\right), 3.3-3.7\left(6 \mathrm{H}, \mathrm{m}^{2}\right.$ two $-\mathrm{CH}_{2}-$ $\mathrm{CH}_{2}-\mathrm{O}-$ and two O-C $\left.\underline{\mathrm{H}}-\mathrm{CH}_{2}-\right), 4.47\left(4 \mathrm{H}, \mathrm{s}\right.$, two $\left.-\mathrm{OCH}_{2} \mathrm{C}_{6} \mathrm{H}_{5}\right), 7.24\left(10 \mathrm{H}\right.$, s, two $\left.\mathrm{CH}_{2}-\mathrm{C}_{6} \underline{\mathrm{H}}_{5}\right)$. Anal. Calcd. for $\mathrm{C}_{25} \mathrm{H}_{34} \mathrm{O}_{4}: \mathrm{C}, 75.34 ; \mathrm{H}, 8.60$. Found: $\mathrm{C}, 75.60 ; \mathrm{H}, 8.81$.

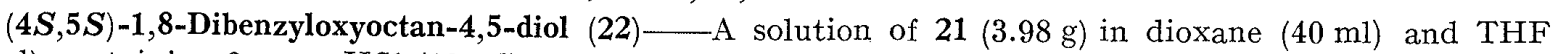
$(25 \mathrm{ml})$ containing $2 \mathrm{~N}$ aq. $\mathrm{HCl}(13 \mathrm{ml})$ was stirred at $70-80^{\circ}$ for $18 \mathrm{hr}$, and then concentrated to a small volume. The residue was poured into ice-cooled satd. aq. $\mathrm{NaHCO}_{3}$, and the whole was extracted with ether. The ethereal extracts were combined, washed with satd. aq. $\mathrm{NaHCO}_{3}$ and satd. aq. $\mathrm{NaCl}$, dried over $\mathrm{MgSO}_{4}$, and evaporated to dryness. The residual oil was purified by column chromatography $\left(\mathrm{CHCl}_{3}-\mathrm{ether}(1: 1)\right)$ to give $22(2.99 \mathrm{~g}, \mathrm{y} .84 \%)$ as a colorless solid. Recrystallization from ether-hexane afforded colorless needles of $\mathrm{mp} 34-35^{\circ},[\alpha]_{\mathrm{D}}^{20}-15.6^{\circ}\left(c=5.57, \mathrm{CHCl}_{3}\right)$. IR $\nu_{\mathrm{max}}^{\mathrm{KBr}} \mathrm{cm}^{-1}: 3340$. NMR $\left(\mathrm{CDCl}_{3}\right) \delta: 1.2-2.0$ (8H, m, two $\left.-\mathrm{CH}-\mathrm{CH}_{2} \mathrm{CH}_{2} \mathrm{CH}_{2} \mathrm{O}-\right), 3.2-3.6\left(8 \mathrm{H}, \mathrm{m}\right.$, two $-\mathrm{OH}$, two $\mathrm{O}-\mathrm{CH}-\mathrm{CH}_{2}-$, and two $\left.\mathrm{CH}_{2} \mathrm{CH}_{2}-\mathrm{O}-\right)$, 4.45 (4H, s, two $\left.-\mathrm{OCH}_{2} \mathrm{C}_{6} \mathrm{H}_{5}\right), 7.23\left(10 \mathrm{H}, \mathrm{s}\right.$, two $\left.\mathrm{CH}_{2}-\mathrm{C}_{6} \underline{\mathrm{H}}_{5}\right)$. Anal. Calcd. for $\mathrm{C}_{22} \mathrm{H}_{30} \mathrm{O}_{4}: \mathrm{C}, 73.71 ; \mathrm{H}, 8.44$. Found: C, 73.47 ; $\mathrm{H}, 8.59$.

$(1 S, 2 S)-1,2-B i s(3-b e n z y l o x y p r o p y l)-18$-crown-6 (23) _- $\mathrm{KOBu}^{t}(213 \mathrm{mg}, 1.90 \mathrm{mmol})$ was added to a

18) E.L. Eliel and A.A. Hartmann, J. Org. Chem., 37, 505 (1972). 
solution of $22(277 \mathrm{mg}, 0.773 \mathrm{mmol})$ in DMSO $(15 \mathrm{ml})$, and the whole was stirred at $50^{\circ}$ for $2 \mathrm{hr}$ under argon. After cooling, a solution of pentaethyleneglycol ditosylate $(432 \mathrm{mg}, 0.79 \mathrm{mmol}$ ) in DMSO (5 ml) was added, and the resulting mixture was stirred at $70-80^{\circ}$ for $18 \mathrm{hr}$. Usual work-up as described above for the preparation of 11 afforded a yellow oil, which was purified by column chromatography (silica gel, ether-AcOEt) to give $23(221 \mathrm{mg}$, y. $51 \%)$ as a colorless oil, $[\alpha]_{\mathrm{D}}^{19.5}-16.3^{\circ}\left(c=3.99, \mathrm{CHCl}_{3}\right)$. IR $v_{\max }^{\mathrm{CHCl}_{3}} \mathrm{~cm}^{-1}: 1094 . \mathrm{NMR}$ $\left(\mathrm{CDCl}_{3}\right) \delta: 1.1-2.0\left(8 \mathrm{H}, \mathrm{m}\right.$, two $\left.-\mathrm{CH}-\mathrm{CH}_{2} \mathrm{CH}_{2} \mathrm{CH}_{2} \mathrm{O}-\right), 3.2-3.9\left(26 \mathrm{H}, \mathrm{m}\right.$, ring protons and two $-\mathrm{CH}_{2} \mathrm{OCH}_{2}-$ $\left.\mathrm{C}_{6} \mathrm{H}_{5}\right), 4.48\left(4 \mathrm{H}\right.$, s, two $\left.-\mathrm{OCH}_{2} \mathrm{C}_{6} \mathrm{H}_{5}\right), 7.20\left(10 \mathrm{H}\right.$, s, two $\left.\mathrm{C}_{6} \underline{\mathrm{H}}_{5}-\right)$. Anal. Calcd. for $\mathrm{C}_{32} \mathrm{H}_{48} \mathrm{O}_{8}: \mathrm{C}, 68.54 ; \mathrm{H}, 8.63$. Found: C, 67.87; H, 8.51.

$(1 S, 2 S)-1,2-B i s(3-h y d r o x y p r o p y l)-18-c r o w n-6(24)$ _-A mixture of $23(221 \mathrm{mg}), 10 \%$ Pd-C (15 mg) and $5 \% \mathrm{HCl}-\mathrm{EtOH}(1 \mathrm{drop})$ in EtOH-THF (1:1) (3 ml) was shaken vigorously under atmospheric pressure of $\mathrm{H}_{2}$ until the absorption of $\mathrm{H}_{2}$ ceased. The catalyst was filtered off, and the filtrate was evaporated to dryness to give crude 24 (143 mg, quantitative) as a colorless oil, which was used in the next step without further purification.

$(1 S, 2 S)$-1,2-Bis(3-tosyloxypropyl)-18-crown-6 (25)__ A mixture of crude 24 (408 $\mathrm{mg}$, ca. $1.07 \mathrm{mmol}$ ) and $\mathrm{TsCl}(641 \mathrm{mg}, 3.36 \mathrm{mmol})$ in pyridine $(5 \mathrm{ml})$ was stirred at $0^{\circ}$ for $48 \mathrm{hr}$. Usual work-up as described above for the preparation of 12 afforded crude $25(630 \mathrm{mg}, \mathrm{y} .84 \%)$ as a pale yellow oil, which was purified by column chromatography (silica gel, ether) to give a colorless oil. $\quad[\alpha]_{\mathrm{p}}^{20}-15.0\left(c=1.56, \mathrm{CHCl}_{3}\right)$. IR $v_{\text {max }}^{\mathrm{rl1m}}$ $\mathrm{cm}^{-1}: 1600,1110$. NMR $\left(\mathrm{CDCl}_{3}\right) \delta: 1.1-2.0\left(8 \mathrm{H}, \mathrm{m}\right.$, two $\left.\mathrm{CH}-\mathrm{CH}_{2} \mathrm{CH}_{2} \mathrm{CH}_{2} \mathrm{O}-\right), 2.44\left(6 \mathrm{H}, \mathrm{s}\right.$, two $\left.\mathrm{CH}_{3}-\mathrm{C}_{6} \mathrm{H}_{4}-\right)$, $3.2-3.8\left(22 \mathrm{H}, \mathrm{m}\right.$, ring protons), $3.9-4.1\left(4 \mathrm{H}, \mathrm{m}\right.$, two $\left.-\mathrm{CH}_{2} \mathrm{CH}_{2} \mathrm{OTs}\right), 7.24$ and $7.65(8 \mathrm{H}, \mathrm{AB}-\mathrm{q}, J=8 \mathrm{~Hz}$, two $\left.\mathrm{CH}_{3}-\mathrm{C}_{6} \mathrm{H}_{4}-\mathrm{SO}_{2}-\right)$.

$(1 S, 2 S)-1,2-B i s[3-(b e n z o y l t h i o)$ propyl]-18-crown-6 (26)-A solution of 25 (742 mg, $1.08 \mathrm{mmol}$ ) and potassium monothiobenzoate $(470 \mathrm{mg}, 2.67 \mathrm{mmol})$ in $\mathrm{EtOH}(20 \mathrm{ml})$ was heated under reflux for $6 \mathrm{hr}$ under $\mathrm{N}_{2}$. Usual work-up as described above for the preparation of 13 afforded an oil, which was purified by column chromatography (silica gel, AcOEt) to give $26(490 \mathrm{mg}, \mathrm{y} .73 \%)$ as a colorless oil. $[\alpha]_{\mathrm{D}}^{20}-19.5^{\circ}(c=3.36$, $\mathrm{MeOH})$. IR $\nu_{\max }^{\mathrm{CHCl}_{3}} \mathrm{~cm}^{-1}: 1660,1110$. NMR $\left(\mathrm{CDCl}_{3}\right) \delta: 1.2-2.0\left(8 \mathrm{H}, \mathrm{m}\right.$, two $\left.-\mathrm{CH}-\mathrm{CH}_{2}-\mathrm{CH}_{2}-\mathrm{CH}_{2}-\mathrm{S}-\right), 3.12$ $\left(4 \mathrm{H}, t, J=7 \mathrm{~Hz}\right.$, two $\left.-\mathrm{CH}_{2}-\mathrm{CH}_{2}-\mathrm{S}-\right), 3.3-3.9\left(22 \mathrm{H}\right.$, m, ring protons), $7.2-7.9\left(10 \mathrm{H}, \mathrm{m}\right.$, two $\left.\mathrm{C}_{6} \mathrm{H}_{5} \mathrm{CO}-\right)$. Anal. Calcd. for $\mathrm{C}_{32} \mathrm{H}_{44} \mathrm{O}_{8} \mathrm{~S}_{2}: \mathrm{C}, 61.91 ; \mathrm{H}, 7.14$. Found: $\mathrm{C}, 61.48 ; \mathrm{H}, 7.09$.

$(1 S, 2 S)-1,2-B i s(3-m e r c a p t o p r o p y l)-18-c r o w n-6 ~(2)-D$-A solution of $26(490 \mathrm{mg}, 0.789 \mathrm{mmol})$ in ether $(15 \mathrm{ml})$ was added dropwise to a suspension of $\mathrm{LiAlH}_{4}(120 \mathrm{mg}, 3.16 \mathrm{mmol})$ in ether $(5 \mathrm{ml})$ under $\mathrm{N}_{2}$, and then the whole was stirred under reflux for $2 \mathrm{hr}$. Usual work-up as described above for the preparation of 1 afforded a pale yellow oil, which was purified by column chromatography (silica gel, ether) to give 2 (143 mg, y. $44 \%)$ as a colorless oil. $[\alpha]_{\mathrm{D}}^{19.5}-26.9^{\circ}\left(c=2.85, \mathrm{CHCl}_{3}\right)$. IR $v_{\max }^{\mathrm{flm}} \mathrm{cm}^{-1}: 2554, \mathrm{NMR}\left(\mathrm{CDCl}_{3}\right) \delta: 1.32(2 \mathrm{H}, \mathrm{t}$, $J=8 \mathrm{~Hz}$, two $-\mathrm{SH}), 1.2-1.9\left(8 \mathrm{H}, \mathrm{m}\right.$, two $\left.-\mathrm{CH}-\mathrm{CH}_{2} \mathrm{CH}_{2} \mathrm{CH}_{2}-\mathrm{SH}\right), 2.54\left(4 \mathrm{H}, \mathrm{q}, J=8 \mathrm{~Hz},-\mathrm{CH}_{2} \mathrm{CH} \mathrm{SH}_{2} \mathrm{SH}, 3.3-\right.$ $3.9\left(22 \mathrm{H}\right.$, m, ring protons). Anal. Calcd. for $\mathrm{C}_{1 \mathrm{~s}} \mathrm{H}_{36} \mathrm{O}_{6} \mathrm{~S}_{2}: \mathrm{C}, 52.39 ; \mathrm{H}, 8.79$. Found: $\mathrm{C}, 52.11 ; \mathrm{H}, 8.70$.

Glycine $p$-Nitrophenyl Ester Hydrobromide (4)-This was prepared according to the reported method ${ }^{19}$ ) as leaflets of $\mathrm{mp} 213-214^{\circ}$ (dec.) (reported ${ }^{19)} \mathrm{mp} 213-215^{\circ}$ (dec.)).

Sarcosine $p$-Nitrophenyl Ester Hydrobromide (5)_- This was prepared according to the reported method $^{20)}$ as leaflets of $\mathrm{mp} 186-188^{\circ}$ (dec.) (reported ${ }^{20)} \mathrm{mp} 189.5-190.5^{\circ}$ ).

$\beta$-Alanine $p$-Nitrophenyl Ester Hydrobromide $(6)$-This was prepared from N-carbobenzyloxy- $\beta$ alanine $p$-nitrophenyl ester ${ }^{21}$ ) by the known method using $25 \% \mathrm{HBr}-\mathrm{AcOH}^{22}$ as leaflets of $\mathrm{mp} 196-196.5$ (from I.tOH-MeOH-ether). Anal. Calcd. for $\mathrm{C}_{4} \mathrm{H}_{11} \mathrm{BrN}_{2} \mathrm{O}_{4}: \mathrm{C}, 37.13 ; \mathrm{H}, 3.81 ; \mathrm{N}, 9.62$. Found: C, 37.62; $\mathrm{H}, 3.76 ; \mathrm{N}, 9.47$.

$\gamma$-Aminobutyric Acid $p$-Nitrophenyl Ester Hydrobromide (7)_— This was prepared from N-carbobenzylcxyl- $\gamma$-aminobutyric acid $p$-nitrophenyl ester ${ }^{23}$ ) by the known method using $25 \% \mathrm{HBr}-\mathrm{AcOH}$, as leaflets of $\mathrm{mp} 160-161^{\circ}$ (from $\mathrm{MeOH}-\mathrm{ether}$ ). Anal. Calcd. for $\mathrm{C}_{1,4} \mathrm{H}_{1 \mathrm{~s}} \mathrm{BrN}_{4} \mathrm{O}_{4}: \mathrm{C}, 39.36 ; \mathrm{H}, 4.29 ; \mathrm{N}, 9.18$. Found: $\mathrm{C}, 39.40 ; \mathrm{H}, 4.26 ; \mathrm{N}, 8.90$.

$\varepsilon$-Aminocaproic Acid $p$-Nitrophenyl Ester Hydrobromide (8)__. This was prepared according to the reported method ${ }^{24)}$ as leaflets of $\mathrm{mp} 114-116^{\circ}$ (reported $^{21)} \mathrm{mp} 112-114^{\circ}$ ).

Measurements of Rate Constants for $p$-Nitrophenol Release from Amino Acid Ester Salts- Pseudofirst-order rate constants for $p$-nitrophenol release were measured by the method reported by $\mathrm{Cram}^{9 a)} \mathrm{using}$ $\mathrm{AcOH}$-pyridine buffer. The results are summarized in Table I.

Acknowledgement The authors are grateful to The Naito Foundation for partial support of this research.

19) M. Goodman and K.C. Stueben, J. Am. Chem. Soc., 81, 3980 (1959).

20) F.H.C. Stewart, Australian J. Chem., 22, 2451 (1969).

21) M. Manning and V. du Vigneaud, Biochemistry, 4, 1884 (1965).

22) D. Ben-Ishai and A. Berger, J. Org. Chem., 17, 1564 (1952).

23) J. de Jersey, Biochemistry, 9, 1761 (1970).

24) L.I. Slobin, Biochemistry, 5, 2836 (1966). 